\title{
Impact of summer drought on forest biodiversity: what do we know?
}

\author{
Frédéric ARCHAUX ${ }^{\mathrm{a} *}$, Volkmar WOLTERS ${ }^{\mathrm{b}}$ \\ ${ }^{a}$ Cemagref, Domaine des Barres, 45290 Nogent sur Vernisson, France \\ b Justus-Liebig-University of Giessen, Heinrich-Buff-Ring 26-32, 35392 Giessen, Germany
}

(Received 14 October 2005; accepted 16 March 2006 )

\begin{abstract}
To date, very few studies have assessed the impact of summer droughts on forest biodiversity and ecosystem functioning. Decreased ecosystem productivity and increased mortality are general consequences of drought on biodiversity. Competitive species, species adapted to cold and wet conditions as well as species with low reproduction rates and/or limited mobility seem the more affected. However, species-specific effects are regulated by mechanisms allowing for resistance to drought. The short-term consequences of drought on biodiversity depend on species abilities to resist, and to recover after, drought, and on competitive interactions between species. Although the abundance of many species generally decreases during drought, some taxa may increase in number during drought or shortly after. The effects of recurrent droughts must be evaluated in the wider context of global climate and habitat change. Considering the predicted increase in drought frequency and intensity, interdisciplinary research initiatives on this issue are needed urgently.
\end{abstract}

drought impact / biodiversity / forests / ecosystem functioning / global change

Résumé - Impact de la sécheresse estivale sur la biodiversité forestière : que savons-nous ? On connaît mal les conséquences des sécheresses sur la biodiversité et le fonctionnement des écosystèmes forestiers. La productivité des écosystèmes semble diminuer et s'accompagne d'une mortalité accrue. Les espèces compétitives, liées à des habitats frais ou humides, avec un faible taux de reproduction et/ou une mobilité réduite semblent les plus sensibles à la sécheresse. La réponse spécifique dépend également des mécanismes de résistance à la sécheresse. Les conséquences à court terme dépendent de la capacité des espèces à résister et à se rétablir de la sécheresse, et de leurs interactions. Un nombre conséquent de taxons peuvent être plus abondants en période de sécheresse ou peu de temps après. Les effets de sécheresses récurrentes sont à replacer dans le cadre du changement climatique global et des modifications d'habitats. Sachant que la fréquence et l'intensité des sécheresses devraient croître dans l'avenir, il est urgent de lancer des recherches interdisciplinaires sur le sujet.

sécheresse / biodiversité / forêts / fonctionnement de l'écosystème / changement global

\section{INTRODUCTION}

The importance of natural hazards in shaping biodiversity has received renewed scientific attention. Experts agree that natural disturbances will increase in frequency and intensity over the next few decades in response to global warming [52]. Both empirical and theoretical work has shown that the frequency and intensity of disturbances influence biodiversity $[80,110]$.

The dramatic effects of the extreme summer drought in 2003 on trees in Western Europe (i.e. mortality, dieback, premature leaf fall) [23] highlight the need to assess the impact of drought on forest biodiversity. All levels of forest biota may be affected, including aboveground (e.g. trees, understory layer) and belowground (e.g. soil microbiota, edaphic invertebrates) species that are intimately related. Therefore, drought may have serious consequences for forest ecosystem functioning.

While scientific interest concerning the impact of global warming on terrestrial ecosystems has increased recently [85, 108], the effects of extreme climatic events on forest ecosystems are still poorly understood [42]. To date, only a few stud-

\footnotetext{
* Corresponding author: frederic.archaux@ cemagref.fr
}

ies have focused on the effects of drought on forest biodiversity (e.g. forest trees $[46,104])$. Even studies attempting to quantify the loss of wood volume following natural disasters have not considered the direct effects of droughts [89, 104].

Investigations on the biological impacts of drought events have focused mainly on arid, semi-arid, and Mediterranean biomes and are biased towards open habitats such as grasslands. Extrapolating results from these habitats to temperate forests is unlikely to be valid. A further limitation is that most existing studies have concentrated on plants (especially trees in temperate regions), pests and herbivorous insects. The conclusions drawn from a few well-studied groups (plants, insects) should not be 'blindly' extrapolated to other components of biodiversity. In addition, most data on which our current knowledge is based are derived from experiments rather than from observations. While experiments simplify the complex feedback systems found in natural conditions, observations generally lack replication and tend to be very short-term. Thus, both approaches are necessary to compensate for their respective shortcomings.

Herein, we summarize the literature on the impact of summer drought on terrestrial biodiversity, with emphasis on forest ecosystems. First, the factors predisposing an organism to 
Table I. Mechanisms of drought resistance.

\begin{tabular}{ll}
\hline Organism & Mechanisms \\
\hline Animals & Thermo-regulation \\
& Moving to more protected areas \\
& Summer diapause \\
Plants & Stomatal closure \\
& Production of antioxidant and compatible \\
& compounds Changes in cell membrane composition \\
& Rapid defoliation \\
& Morphological adaptation (e.g. deep-rooting) \\
& Seed bank \\
\hline
\end{tabular}

drought or, conversely, conferring drought-resistance are reviewed. Second, the short- (one or two years after the drought event) and mid-term (a decade or so) consequences of drought on biodiversity are assessed. Third, the long-term (decades or more) consequences of drought combined with other global changes on biodiversity are considered. There is evidence that drought effects may be less severe during summer than during other seasons of the year [39]. However, this review examines the effects of summer drought events only. Intensity [35,91], duration [30] and frequency [79] of droughts also influence biodiversity, with data suggesting that the duration of a drought event may be more important than its intensity [30] and that the impact of a single extreme drought may depend on the overall temporal trend in drought intensity [54]. Extreme temperatures, usually associated with summer drought, also amplify environmental stress [5]. Unfortunately, these issues cannot be covered here due to the limited number of adequate studies (but see [11] for details on eco-physiology).

\section{DROUGHT RESISTANCE AND PREDISPOSING FACTORS}

Table I summarizes resistance mechanisms of animals and plants. Organisms can cope with drought/heat by escaping these conditions (e.g. by moving in shaded areas) and/or by alleviating the damaging effect of the physiological stress (e.g. by producing compatible compounds to limit the osmotic stress). Details on physiological adaptation to drought by plants can be found in [7, 11, 112], by insects in [4] and by vertebrates in [69]. Analogies can be drawn between diapausing insects and seeds stored in a seed bank. In insects, summer diapause aims primarily at escaping drought and may occur at all developmental stages (from larval to adult) and may be facultative or not. Different environmental factors such as number of daylight hours or temperature may lengthen or terminate the diapause in a species-specific way $[4,51,59]$.

Many factors can predispose organisms to drought in the short- and mid-term (Tab. II). These factors are difficult to summarize because of sparse and sometimes conflicting evidence. Moreover, some of the supposed 'predisposing factors' have never been scientifically proven.

At the individual level, the effects of drought may be influenced by genotype, age and location. Indeed, very young or very old individuals are typically the primary victims of drought events. Furthermore, individuals at the southern limits of their geographical distribution may be particularly affected by drought, as a species range is often determined by its physiological tolerance. Forest management that maximises leaf area index and/or favours species in regions close to the maximal heat- or water stress-tolerance limits of the species may threaten entire forest stands [45]. At the species level, the effects of drought are influenced by life history and ecological traits, such as anatomical or morphological adaptations (e.g. leaf size, depth of roots, Tab. II). At the ecosystem scale, the main effects of drought may occur indirectly, with droughts promoting the occurrence and/or increasing the intensity of other natural or anthropogenic pressures. One of the most striking examples is the dramatic increase of Mediterranean forest fires during dry years. The higher likelihood of insect attacks on water-stressed plants or trees is not a universal phenomenon (e.g. [16,44]), but boring and sucking insects usually perform better on stressed plants (the contrary has been reported for gall-making and chewing insects [24,56]).

There seems to be a general consensus that species-poor ecosystems are usually more sensitive to perturbations, such as droughts, than species-rich ecosystems [50]. For instance, a positive relationship was found between total biomass and species richness of naturally co-occurring mosses and liverworts under experimental drought conditions but not under constant conditions [73]. One explanation for the positive relationship between species richness and overall drought resistance may be that impoverished ecosystems may host fewer species or groups that are capable of a differential functional response [70]. For instance, a decrease in both total abundance and species richness of Collembola communities is associated with a strong reduction in decomposition rate [82]. However, ecosystem resistance and resilience are often unrelated to total species richness, the number of plant functional groups or the number of trophic levels (e.g. [109]). For instance, high functional redundancy has been found among forest soil microarthropods, so that the positive relationship between species richness and ecosystem functions would appear only for very low values of species richness [62]. Several studies have even emphasized the species-specific drought response of plants $[14,66]$, root mycorrhizae [55] and butterflies [92]. Idiosyncratic responses suggest that simple physiological models may not be sufficient to predict the effect of drought on whole communities [21,38]. Furthermore, response patterns at the community level are also regulated by complex interactions between the different components of trophic chains. For example, a greater abundance of insect parasitoids and arthropod predators of European corn borer larvae (Ostrinia nubilialis Hubner) in drought-stressed corn fields compensated for the corn's greater susceptibility to the larvae [38].

\section{SHORT- AND MID-TERM EFFECTS OF DROUGHT}

Observed and potential short- and mid-term impacts of a drought event are listed in Table III. Short-term responses may differ from mid- and long-term responses because (1) 
Table II. Observed and potential (in italics) factors predisposing taxa to drought impact. A distinction is made between factors that may vary between individuals of the same species, between phylogenetically-related species (but not between individuals of the same species) or between ecosystems (but not between species within the same ecosystem).

\begin{tabular}{|c|c|c|}
\hline Level & Predisposing factor & Taxa and references \\
\hline Individual & $\begin{array}{l}\text { Location near species' range boundary } \\
\text { Location in a shaded place } \\
\text { Age (young and old individuals) } \\
\text { Not entering diapause (when facultative) } \\
\text { Drought intolerant genotype }\end{array}$ & $\begin{array}{l}\text { Tree [22], butterflies [99] } \\
\text { Plants }[76,107] \\
\text { Trees }[28,61,79] \\
\text { Grassland flies [74] } \\
\text { Never demonstrated }\end{array}$ \\
\hline Species & $\begin{array}{l}\text { Large leaf-area } \\
\text { Competitive } \\
\text { Preference for cool or wet habitats } \\
\text { Absence of ground reserves } \\
\text { Shallow roots } \\
\text { Low reproduction rate } \\
\text { Low mobility } \\
\text { Specific competition } \\
\text { Not diapausing }\end{array}$ & $\begin{array}{l}\text { Trees }[5,18] \\
\text { Temperate grassland herbs }[25,72] \text { but maybe not temperate forest understory } \\
\text { plants }[71] \\
\text { Forest plants }[14,106] \text {, temperate Carabids and butterflies but not moths [71] } \\
\text { Temperate herbaceous plants }[15] \\
\text { Temperate grassland herbs }[14,25,72] \\
\text { Temperate and Mediterranean grassland herbs }[15,66,72] \\
\text { Temperate butterflies but not moths }[71] \\
\text { Temperate forest understory plants }[33] \text { but see }[12,26]^{1} \\
\text { Never demonstrated }\end{array}$ \\
\hline Ecosystem & $\begin{array}{l}\text { Disturbed ecosystems } \\
\text { Susceptibility to fire } \\
\text { Susceptibility to chemicals } \\
\text { Susceptibility to pest attack and disease } \\
\text { Susceptibility to invasion }\end{array}$ & $\begin{array}{l}\text { Temperate grassland herbs [14], temperate mosses [73], temperate forest } \\
\text { Collembolans [82] } \\
\text { Mediterranean shrubs [65], Mediterranean forest Carabids [31], Mediter- } \\
\text { ranean birds [47] } \\
\text { Temperate forest and boreal grassland Collembolans }[48,58] \text { but see [61] } \\
\text { Various plants and trees [17,90] but see }[16,44] \\
\text { Never demonstrated }\end{array}$ \\
\hline
\end{tabular}

\footnotetext{
${ }^{1}$ This may depend on the soil properties [18], temperature [21] and level of water supply and on the aspect of plant performance examined [87].
}

the impact of a drought event may appear primarily during a prolonged recovery phase rather than during the event itself [25, 42], and (2) resistance and resilience to drought may be negatively linked, as was found for herbaceous plant communities [67]. In the latter study, five herbaceous communities representing a wide range of functional types were experimentally subjected to drought in Great Britain. Fast-growing (resilient) species tended to be more sensitive to damage by drought than slow-growing species [67].

Lower productivity (as measured as changes in biomass or cover over time) and higher mortality are the most widespread effects of drought on plants. In two prairie grasslands, a major drought caused the annual production, which had been nearly constant previously, to oscillate every two years for at least nine years after the event, showing that drought impact on ecosystem productivity may last far beyond the event itself [43]. More fertile, early-successional ecosystems may be more vulnerable to drought, as found for British grasslands [41].

As for plants, desiccation during drought periods may increase the mortality rate of some insects [111], while other species may remain largely unaffected $[71,88]$. Drought may even favour some taxa $[68,71]$. In fact, high temperatures usually stimulate an insect's growth, allowing multivoltine species (i.e. species that produce several broods in a single season) to produce more generations per year. Furthermore, with the ex- ception of species whose diapause is under strict photoperiodic control [51], high temperatures may induce or extend summer diapause [4]. Diapausing individuals are known to enjoy better survival and fecundity than non-diapausing ones [74, 113]. Information on the effects of the 2003 drought on forest insect populations can be found in [86].

To date, data on the short- and mid-term consequences of drought on biodiversity are almost completely confined to studies in grasslands. Forest biodiversity, and especially vegetation, may be particularly resistant to drought. According to annual surveys on $124 \times 100 \mathrm{~m}^{2}$ plots of the French RENECOFOR long-term monitoring programme, for instance, changes in community composition were small after the extreme 2003 drought (J.-L. Dupouey, pers. com.). A response, if any, is more likely to result from canopy opening after drought [79] than from the drought itself, with shifts in plant community composition becoming apparent only several years after the drought, until the canopy closes again. Current knowledge on the impact of thinning cuts on herbaceous vegetation suggests that small changes in canopy cover will probably increase the number, the abundance and the flowering rate of forest plant species $[6,100]$.

Another potential positive impact of drought on forest biodiversity relates to the increased amount of standing (snags) and lying deadwood (branches, logs) [105]. Managed forests are characterized by low deadwood volumes per ha compared 
Table III. Short- and mid-term, observed and potential (in italics), consequences of drought on biodiversity. A distinction is made between factors operating primarily at the individual, species and ecosystem levels (see legend of Tab. II).

\begin{tabular}{lll}
\hline Level & Short-term consequences & Taxa and references \\
\hline Individual & Reduced growth & Forest plants [39] \\
& Reduced fecundity & Plants [34], soil microarthropods [62], butterflies [84] \\
& Increased mortality & Trees [78] but see [71] for grassland herbs and insects \\
& & \\
Species & Increase of deadwood-dwelling species & Saproxylic insect and fungi [24] \\
& Shift in species range & Never demonstrated \\
& Increase of drought-tolerant species & Never demonstrated \\
& & \\
Ecosystem & Reduced productivity & Boreal forest understory plants [13], temperate forest Collembolans [82], \\
& Slower ecosystem functioning & boreal forest birds [8] \\
& Decrease in local species richness & Temperate grassland herbs with accumulation of litter [25] \\
& Shift in species interactions & Boreal forest understory plants [75], temperate forest Collembolans [82] \\
& Shift in species composition & Mountain grassland herbs [19] \\
& & Temperate grassland soil microarthropods [63] \\
& Mid-term consequences & Organisms and references \\
Level & Lasting growth reduction & Trees [76, 79,97] \\
Individual & Telayed mortality & Trees [11,78] \\
& Susceptibility to pathogens and disease & Trees [110] \\
& Reduced offspring performance & Grassland moths (males that do not diapause [113])
\end{tabular}

\begin{tabular}{|c|c|c|}
\hline Species & $\begin{array}{l}\text { Increase of drought-tolerant species } \\
\text { Microevolutionary changes } \\
\text { Increase of deadwood-dwelling species } \\
\text { Shift in species range }\end{array}$ & $\begin{array}{l}\text { Temperate forest understory plants }[10 \\
\text { Tropical island birds }[10] \\
\text { Never demonstrated } \\
\text { Never demonstrated }\end{array}$ \\
\hline Ecosystem & $\begin{array}{l}\text { Oscillations in productivity } \\
\text { Shift in species composition } \\
\text { Shift in species interactions } \\
\text { Reduced species richness }\end{array}$ & $\begin{array}{l}\text { Temperate grassland herbs }[43,103] \\
\text { Mountain grassland herbs }[95] \\
\text { Never demonstrated } \\
\text { Never demonstrated }\end{array}$ \\
\hline
\end{tabular}

to old-growth or primary forests [105]. Therefore, even a small increase in deadwood in managed forests may have considerable ecological consequences [37]. In Scandinavia, about $25 \%$ of all forest species depend on deadwood (including fungi, insects, mosses, vertebrates and nematodes) [93].

Due to the lack of a global, standardised assessment of drought susceptibility for even the most common animal and plant taxa, the increase in drought-tolerant species after drought events has never been proven scientifically. For instance, there is no Ellenberg-like [27] index for drought resistance in vascular plants. Only surrogates for species drought-tolerance such as preference for cool or wet habitats or morphological traits (e.g. ground reserves, root depth for plants) have been used to assess the impact of droughts (e.g. $[14,71])$.

The assessment of species susceptibility to drought will be an important step for understanding the impact of drought on forest biodiversity but it probably will not be sufficient. The response of communities to drought likely is more than just the sum of the individual responses of species because drought effects often are mediated through biological interactions. For example, drought may reduce the cover of perennial plants (see above; [71]) or prevent colonisation of poor soils by dominant plants [83]. This provides refuges for tap-rooted plants [14] and allows rapid colonisation by annuals or biannuals [15] from dormant or newly-dispersed seeds [57]. In one alpine meadow site, dominant grasses decreased in cover following an extreme, 4-year drought period; they had not recovered their initial cover nine years later because other species with a higher regenerative capacity had colonised [95]. In some cases, the identity of the dominant species in the herb layer may be determined by drought-resistance and competitive ability, with the outcome depending on the relative importance of the two phenomena. For example, Bromus erectus Huds. is usually excluded from calcareous grasslands in France by competition with Brachypodium pinnatum (L.) Beauv., but dominates in areas with high water-stress due to the greater drought sensitivity 
of the latter species [19]. Relaxed inter-specific competition probably explains why the richness of bryophytes in Southern Norwegian old-growth coniferous forests [75] and of vascular plants in British grasslands [71] increased shortly after drought. Thus, an initial decrease in richness immediately after drought may be followed by an increase in richness, both at very local ( $\alpha$ diversity) and larger spatial scales ( $\gamma$ diversity), either in a few years' time and/or over a much longer time period.

\section{LONG-TERM EFFECTS OF DROUGHT AND GLOBAL CHANGE}

Drought frequency is thought to be the main driver of vegetation dynamics in Mediterranean [102], boreal [94, 101] and temperate forests [64]. For example, the decline of oak in Europe has been linked to the detrimental effects of recurrent droughts $[60,98]$. Similarly, summer drought is thought to be one of the factors that helped hazel to out-compete oak in the southern Alps 11000-10500 cal yr BP [32]. Species can be expected to shift their distribution in response to the new selection pressures, adapt or become extinct. Current changes in geographic ranges of many species have been linked to global warming in general, but extreme weather events, such as droughts, provide an alternative explanation [77].

Extreme events such as droughts may generate intense episodes of natural selection [3,42]. Selection for droughttolerant genotypes may thus cause micro-evolutionary changes. However, evidence for natural selection acting upon a heritable variation in traits increasing drought tolerance is lacking (but see [10]), although populations exposed to different drought frequencies often have corresponding levels of drought-tolerance that are genetically fixed. Examples can be found in $[1,53,81]$ for plants and in [92] for insects. The flora and fauna that still exists in the Northern Hemisphere survived extreme climatic episodes during the Pleistocene. Therefore, contemporary climatic changes can be expected to cause relatively few extinctions. However, most extant taxa in the Northern Hemisphere have been selected to resist winter cold rather than summer drought or extreme heat (see [96] for plants and [9] for birds). Furthermore, the genus-level conservatism in climatic requirements observed in Northern Hemisphere tree species [96] and the selection acting simultaneously on antagonistic traits (e.g. dispersal/survival and fecundity, stressresistance and resilience) [29] may well prevent species from adapting to rapidly changing environmental conditions. Additionally, the combinations of conditions that exist today may change in the future, with past and present climatic conditions failing to provide a suitable analogue. These changes may lead to combinations of species that have never co-occurred before [2]. Finally, long-term impacts of droughts will depend not only on drought frequency and intensity, but will be intimately linked to the effects of other atmospheric, climatic and habitat changes also. Most of these changes interact in complex ways $[36,39]$. For instance, high rates of atmospheric nitrogen deposition may reduce inter-specific plant competition whilst a slow climatic warming may have little effect [40].
Overall, therefore, we lack sufficient data for making reliable predictions on the adaptive potential of species to the simultaneous action of several drivers of global change [49].

\section{CONCLUSION AND RESEARCH NEEDS}

Drought is certainly a widely underestimated ecological stress and selection force [42]. Our review has revealed a number of issues that should have priority in future research:

1. Variations of factors such as drought intensity, duration and return frequency, species-specific phenotypic plasticity, adaptive potential and phylogenetic and physiological constraints must be experimentally identified in relation to drought events. This should lead to a concise classification of species according to their sensitivity to drought or to environmental features linked to drought. Particular focus must be on vulnerable species and ecosystems, because these will probably be the first to be seriously affected by drought.

2. The impact of drought on ecosystem processes must be studied to better understand how drought alters ecological functions and how these effects are influenced by species composition. Points 1 and 2 should help to define an indicator system for predicting drought sensitivity at the stand and forest levels.

3. Research should focus on the simultaneous effects of drought and other factors, such as forest management, pollution and global warming. This is essential for identifying the most relevant factors that mediate the impact of drought events on forest biodiversity. The impact of strategies that are being proposed to mitigate the effects of drought on trees on forest biodiversity should be rapidly evaluated, especially the impact of the plantation of drought-tolerant tree species and of the reduction of the rotation length [20].

4. Long-term monitoring programs should be continued or developed, since these are the only way for evaluating the impact of rare events on ecosystems. However, these programs should be coupled with integrative experimental and modelling approaches to enhance our understanding of complex drought effects.

5. The effects of drought events on forest biodiversity should be considered in both planning (e.g. tree species selection) and management (e.g. retention of deadwood).

Acknowledgements: We would like to thank Christophe Bouget, Mike D. Morecroft and G. Landmann and one referee for their constructive comments on an earlier version of this paper.

\section{REFERENCES}

[1] Abrams M.D., Genotypic and phenotypic variation as stress adaptations in temperate tree species: a review of several case studies, Tree Physiol. 14 (1994) 833-842.

[2] Ackerly D.D., Community assembly, niche conservatism, and adaptive evolution in changing environments, Int. J. Plant Sci. 164 (2003) 165-184. 
[3] Ackerly D.D., Canopy gaps to climate change - extreme events, ecology and evolution, New Phytol. 160 (2003) 2-4.

[4] Bale J.S., Masters G.J., Hodkinson I.D., Awmack C., Bezemer T.M., Brown V.K., Butterfield J., Buse A., Coulson J.C., Farrar J., Good J.E.G., Harrington R., Hartley S., Jones T.H., Herbivory in global climate change research: direct effects of rising temperature on insect herbivores, Glob. Change Biol. 8 (2002) 1-16.

[5] Bassow S.L., McConnaughay K.D.M., Bazzaz F.A., The response of temperate tree seedlings grown in elevated $\mathrm{CO}_{2}$ to extreme temperature events, Ecol. Appl. 4 (1994) 593-560.

[6] Bergès L., Rôle des coupes, de la stratification verticale et du mode de traitement sur la biodiversité, in: Gosselin M., Laroussinie O. (Eds.), Gestion forestière et biodiversité : connaître pour préserversynthèse bibliographique, Cemagref éditions, Antony, 2004, p. 165.

[7] Berry J.A., Björkman O., Photosynthetic response and adaptation to temperature in higher plants, Annu. Rev. Plant Physiol. 31 (1980) 491-543.

[8] Blake J., Hanowski J., Niemi G., Collins P., Annual variation in bird populations of mixed-conifer Northern hardwood forests, Condor 96 (1994) 381-399.

[9] Blondel J., Mourer-Chauviré C., Evolution and history of the western Palearctic avifauna, Trends Evol. Ecol. 13 (1998) 488-492.

[10] Boag P.T., Grant P.R., The classical case of character release: Darwins finches (Geospiza) on Isla Daphne Major, Galapagos, Biol. J. Linn. Soc. 22 (1984) 243-287.

[11] Bréda N., Huc R., Granier A., Forest trees and stands under drought: a review of ecophysiological responses, adaptations and consequences, Ann. For. Sci. 63 (2006) 623-642.

[12] Britton A., Marrs R., Pakeman R., Carey P., The influence of soil-type, drought and nitrogen addition on interactions between Calluna vulgaris and Deschampsia flexuosa: implications for heathland regeneration, Plant Ecol. 166 (2003) 93-105.

[13] Brunet J., Tyler G., Interannual variability in abundance of field layer species in a south Swedish deciduous wood, Flora 195 (2000) 97-103.

[14] Buckland S.M., Grime J.P., Hodgson J.G., Thompson K., A comparison of plant responses to the extreme drought of 1995 in northern England, J. Ecol. 85 (1997) 875-882.

[15] Buckland S.M., Thompson K., Hodgson J.G., Grime J.P., Grassland invasions: effects of manipulations of climate and management, $\mathrm{J}$ Appl. Ecol. 38 (2001) 301-309.

[16] Bultman T.L., Bell G.D., Interaction between fungal endophytes and environmental stressors influences plant resistance to insects, Oikos 103 (2003) 182-190.

[17] Cannon R.J.C., The implications of predicted climate change for insect pests in the UK, with emphasis on non-indigenous species, Glob. Change Biol. 4 (1998) 785-796.

[18] Coomes D.A., Grubb P.J., Impacts of root competition in forests and woodlands: a theoretical framework and review of experiments, Ecol. Monogr. 70 (2000) 171-207.

[19] Corcket E., Liancourt P., Callaway R.M., Michalet R., The relative importance of competition for two dominant grass species is affected by environmental manipulations in the field, Ecoscience 10 (2003) 186-194.

[20] Dale V.H., Joyce L.A., McNulty S., Neilson R.P., Ayres M.P., Flannigan M.D., Hanson P.J., Irland L.C., Lugo A.E., Peterson C.J., Simberloff D., Swanson F.J., Stocks B.J., Wotton B.M., Climate change and forest disturbances, Bioscience 51 (2001) 723-734.

[21] Davis A.J., Lawton J.H., Shorrocks B., Jenkinson L.S., Individualistic species responses invalidate simple physiological models of community dynamics under global environmental change, J. Anim. Ecol. 67 (1998) 600-612.

[22] Drohan P., Stout S., Petersen G., Sugar maple (Acer saccharum Marsh.) decline during 1979-1989 in northern Pennsylvania, For. Ecol. Manage. 170 (2002) 1-17.
[23] Département de la Santé des Forêts, Sécheresse et canicule de l'été 2003, Quelle incidence visuelle sur les peuplements forestiers ? DSF, Ministère de l'Agriculture, de l'Alimentation, de la Pêche et des Affaires Rurales, Paris, 2004.

[24] Desprez-Loustau M.-L., Marçais B., Nageleisen L.-M., Piou D., Vannini A., Interactive effects of drought and pathogens in forest trees, Ann. For. Sci. 63 (2006) 595-610.

[25] Dunnett N.P., Willis A.J., Hunt R., Grime J.P., A 38 year study of relations between weather and vegetation dynamics in road verges near Bibury, Gloucestershire, J. Ecol. 86 (1998) 610-623.

[26] Eber W., On the light climate in the forests near Gottingen and its influence on the ground flora, Scripta Geobot. 3 (1972) 150.

[27] Ellenberg H., Weber H.E., Düll R., Wirth V., Werner W., Paulißen D., Zeigerwerte von Pflanzen in Mitteleuropa, Verlag Goltze, Göttingen, 1992.

[28] Elliott K.J., Swank W.T., Impacts of drought on tree mortality and growth in a mixed hardwood forest, J. Veg. Sci. 5 (1994) 229-236.

[29] Etterson J.R., Shaw R.G., Constraint to adaptative evolution in response to global warming, Science 294 (2001) 151-154.

[30] Fay P., Carlisle J., Knapp A., Blair J., Collins S., Altering rainfall timing and quantity in a mesic grassland ecosystem: design and performance of rainfall manipulation shelters, Ecosystems 3 (2000) 308-319.

[31] Fernández Fernández M.M., Salgado Costas J.M., Recolonization of a burnt pine forest (Pinus pinaster) by Carabidae (Coleoptera), Eur. J. Soil Biol. 40 (2004) 47-53.

[32] Finsinger W., Tinner W., van der Knaap W., Ammann B., The expansion of hazel (Corylus avellana L.) in the southern Alps: a key for understanding its early Holocene history in Europe? Q. Sci. Rev. 25 (2006) 612-631.

[33] Fotelli M.N., Geßler A., Peuke A.D., Rennenberg H., Drought affects the competitive interactions between Fagus sylvatica seedlings and an early successional species, Rubus fruticosus: responses of growth, water status and 13C composition, New Phytol. 151 (2001) 427-435.

[34] Fox L., Ribeiro S., Brown V., Masters G., Clarke I., Direct and indirect effects of climate change on St John's wort, Hypericum perforatum L. (Hypericaceae), Oecologia 120 (1999) 113-122.

[35] Frelich L.E., Reich P.B., Neighborhood effects, disturbance severity, and community stability in forests, Ecosystems 2 (1999) 151166.

[36] Fuhrer J., Agroecosystern responses to combinations of elevated $\mathrm{CO}_{2}$, ozone, and global climate change, Agr. Ecosyst. Environ. 97 (2003) $1-20$.

[37] Gibb H., Pettersson R., Hjältén J., Hilszczanski J., Ball J., Johansson T., Atlegrim O., Danell K., Conservation-oriented forestry and early successional saproxylic beetles: responses of functional groups to manipulated dead wood substrates, Biol. Conserv. 129 (2006) 437-450.

[38] Godfrey L., Godfrey K., Hunt T., Spomer S., Natural enemies of European corn-borer Ostrinia nubilialis (Hubner) (Lepidoptera, Pyralidae) larvae in irrigated and drought-stressed corn, J. Kansas Entomol. Soc. 64 (1991) 279-286.

[39] Gordon C., Woodin S.J., Alexander I.J., Mullins C.E., Effects of increased temperature, drought and nitrogen supply on two upland perennials of contrasting functional type: Calluna vulgaris and Pteridium aquilinum, New Phytol. 142 (1999) 243-258.

[40] Gordon C., Woodin S.J., Mullins C.E., Alexander I.J., Effects of environmental change, including drought, on water use by competing Calluna vulgaris (Heather) and Pteridium aquilinum (Bracken), Funct. Ecol. 13 (1999) 96-106.

[41] Grime J.P., Brown V.K., Thompson K., Masters G.J., Hillier S.H., Clarke I.P., Askew A.P., Corker D., Kielty J.P., The response of two contrasting limestone grasslands to simulated climate change, Science 289 (2000) 762-765. 
[42] Gutschick V.P., BassiriRad H., Extreme events as shaping physiology, ecology, and evolution of plants: toward a unified definition and evaluation of their consequences, New Phytol. 160 (2003) 21-42.

[43] Haddad N.M., Tilman D., Knops J.M.H., Long-term oscillations in grassland productivity induced by drought, Ecol. Lett. 5 (2002) 110-120.

[44] Hale B.K., Bale J.S., Pritchard J., Masters G.J., Brown V.K., Effects of host plant drought stress on the performance of the bird cherryoat aphid, Rhopalosiphum padi (L.): a mechanistic analysis, Ecol. Entomol. 28 (2003) 666-677.

[45] Hansen A.J., Neilson R.P., Dale V.H., Flather C.H., Iverson L.R., Currie D.J., Shafer S., Cook R., Bartlein P.J., Global change in forests: responses of species, communities, and biomes, Bioscience 51 (2001) 765-779.

[46] Hanson P., Weltzin J., Drought disturbance from climate change: response of United States forests, Sci. Tot. Environ. 262 (2000) 205220 .

[47] Herrando S., Brotons L., Llacuna S., Does fire increase the spatial heterogeneity of bird communities in Mediterranean landscapes? Ibis 145 (2003) 307-317.

[48] Højer R., Bayley M., Damgaard C.F., Holmstrup M., Stress synergy between drought and a common environmental contaminant: studies with the collembolan Folsomia candida, Glob. Change Biol. 7 (2001) 485-494.

[49] Holt R.D., The microevolutionary consequences of climate change, Trends Evol. Ecol. 5 (1990) 311-315.

[50] Hooper D.U., Chapin F.S., Ewel J.J., Hector A., Inchausti P., Lavorel S., Lawton J.H., Lodge D.M., Loreau M., Naeem S., Schmid B., Setala H., Symstad A.J., Vandermeer J., Wardle D.A., Effects of biodiversity on ecosystem functioning: a consensus of current knowledge, Ecol. Monogr. 75 (2005) 3-35.

[51] Imai C., Photoperiodic induction and termination of summer diapause in adult Epilachna admirabilis (Coleoptera: Coccinellidae) from a warm temperate region, Eur. J. Entomol. 101 (2004) 523529.

[52] International Panel on Climate Change, IPCC Third Assessment Report: Climate Change 2001, Cambridge University Press, Cambridge, 2001.

[53] Joshi J., Schmid B., Caldeira M.C., Dimitrakopoulos P.G., Good J., Harris R., Hector A., Huss-Danell K., Jumpponen A., Minns A., Mulder C.P., Pereira J.S., Prinz A., Scherer-Lorenzen M., Terry A.C., Troumbis A.Y., Lawton J.H., Local adaptation enhances performance of common plant species, Ecol. Lett. 4 (2001) 536-544.

[54] Kemp W., Cigliano M., Drought and rangeland grasshopper species diversity, Can. Entomol. 126 (1994) 1075-1092.

[55] Klironomos J., Hart M., Gurney J., Moutoglis P., Interspecific differences in the tolerance of arbuscular mycorrhizal fungi to freezing and drying, Can. J. Bot. 79 (2001) 1161-1166.

[56] Koricheva J., Larsson S., Haukioja E., Insect performance on experimentally stressed woody plants: a meta-analysis, Annu. Rev. Entomol. 43 (1998) 195-216.

[57] Kotanen P.M., Effects of gap area and shape on recolonization by grassland plants with differing reproductive strategies, Can. J. Bot. 75 (1997) 352-361.

[58] Kuperman R.G., Potapov M.B., Sinitzina E.A., Precipitation and pollution interaction effect on the abundance of Collembola in hardwood forests in the lower Midwestern United States, Eur. J. Soil Biol. 38 (2002) 277-280.

[59] Ishikawa Y., Yamashita T., Nomura M., Characteristics of summer diapause in the onion maggot, Delia antiqua (Diptera: Anthomyiidae), J. Ins. Physiol. 46 (2000) 161-167.

[60] Landmann G., Role of climate, stand dynamics and past management in forest declines: review of ten years of field ecology in France, in: Huettl R.F., Mueller-Dombois D. (Eds.), Forest Decline in the Atlantic and Pacific regions, Springer Verlag, New-York, 1993, pp. 18-39.
[61] LeBlanc D.C., Interactive effects of acidic deposition, drought, and insect attack on oak populations in the midwestern United States, Can. J. Forest Res. 28 (1998) 1184-1197.

[62] Liiri M., Setala H., Haimi J., Pennanen T., Fritze H., Relationship between soil microarthropod species diversity and plant growth does not change when the system is disturbed, Oikos 96 (2002) 137-149.

[63] Lindberg N., Engtsson J.B., Persson T., Effects of experimental irrigation and drought on the composition and diversity of soil fauna in a coniferous stand, J. Appl. Ecol. 39 (2002) 924-936.

[64] Lindner M., Bugmann H., Lasch P., Flechsig M., Cramer W., Regional impacts of climatic change on forests in the state of Brandenburg, Germany, Agric. For. Meteorol. 84 (1997) 123-135.

[65] Lloret F., Pausas J., Vilà M., Responses of Mediterranean plant species to different fire frequencies in Garraf Natural Park (Catalonia, Spain): field observations and modeling predictions, Plant Ecol. 167 (2003) 223-235.

[66] Lloret F., Peñuelas J., Estiarte M., Experimental evidence of reduced diversity of seedlings due to climate modification in a Mediterranean-type community, Glob. Change Biol. 10 (2004) 248258.

[67] MacGillivray C.W., Grime J.P., Band S.R., Booth R., Campbell B., Hendry G., Hillier S., Hodgson J., Hunt R., Jalili A., Mackey J., Mowforth M., Neal A., Reader R., Rorison I., Spencer R., Thompson K., Thorpe P.C., Testing predictions of the resistance and resilience of vegetation subjected to extreme events, Funct. Ecol. 9 (1995) 640-649.

[68] Mattson W.J. Jr., Haack R.A., The role of drought in outbreaks of plant-eating insects, Bioscience 37 (1987) 110-118.

[69] McArthur A.J., Thermal interaction between animal and microclimate: a comprehensive model, J. Theor. Biol. 126 (1987) 203-238.

[70] McCann K.S., The diversity-stability debate, Nature 405 (2000) 228-233.

[71] Morecroft M.D., Bealey C.E., Howells E., Rennie S., Woiwod I.P., Effects of drought on contrasting insect and plant species in the UK in the mid-1990s, Glob. Ecol. Biogeogr. 11 (2002) 7-22.

[72] Morecroft M.D., Masters G.J., Brown V.K., Clarke I.P., Taylor M.E., Whitehouse A.T., Changing precipitation patterns alter plant community dynamics and succession in an ex-arable grassland, Funct. Ecol. 18 (2004) 648-655.

[73] Mulder C.P.H., Uliassi D.D., Doak D.F., Physical stress and diversity-productivity relationships: the role of positive interactions, Proc. Natl. Acad. Sci. USA 98 (2001) 6704-6708.

[74] Nomura M., Ishikawa Y., Dynamic changes in cold hardiness, hightemperature tolerance and trehalose content in the onion maggot, Delia antiqua (Diptera: Anthomyiidae), associated with the summer and winter diapause, Appl. Entomol. Zool. 36 (2001) 443-449.

[75] Okland R.H., Eilertsen O., Dynamics of understory vegetation in an old-growth boreal coniferous forest, 1988-1993, J. Veg. Sci. 7 (1996) 747-762.

[76] Orwig D.A., Abrams M.D., Variation in radial growth responses to drought among species, site, and canopy strata, Trees 11 (1997) 474-484.

[77] Parmesan C., Root T., Willig M., Impacts of extreme weather and climate on terrestrial biota, Bull. Am. Meteorol. Soc. 81 (2000) 443-450.

[78] Pedersen B.S., The role of stress in the mortality of midwestern oaks as indicated by growth prior to death, Ecology 79 (1998) 79-93.

[79] Peterken G.F., Mountford E.P., Effects of drought on beech in Lady Park Wood, an unmanaged mixed deciduous woodland, Forestry 69 (1996) 125-136.

[80] Petraitis P.S., Latham R.E., Neisenbaum R.A., The maintenance of species diversity by disturbance, Q. Rev. Biol. 64 (1989) 393-418. 
[81] Peuke A.D., Schraml C., Hartung W., Rennenberg H., Identification of drought-sensitive beech ecotypes by physiological parameters, New Phytol. 154 (2002) 373-387.

[82] Pflug A., Wolters V., Rusek J., Influence of drought and litter age on Collembola communities, Eur. J. Soil Biol. 37 (2001) 305-308.

[83] Piper J.K., Composition of prairie plant communities on productive versus unproductive sites in wet and dry years, Can. J. Bot. 73 (1995) 1635-1643.

[84] Pollard E., Greatorex-Davies J.N., Thomas J.A., Drought reduces breeding success of the butterfly Aglais urticae, Ecol. Entomol. 22 (1997) 315-318.

[85] Root T.L., Price J.T., Hall K.R., Schneider S.H., Rosenzweig C., Pounds J.A., Fingerprints of global warming on wild animals and plants, Nature 421 (2003) 57-60.

[86] Rouault G., Candau J.-N., Lieutier F., Nageleisen L.-M., Martin J.-C., Warzee N., Effects of drought and heat on forest insect populations in relation to the 2003 drought in Western Europe, Ann. For. Sci. 63 (2006) 611-622.

[87] Ross A.L., Foster B.L., Loving G.S., Contrasting effects of plant neighbours on invading Ulmus rubra seedlings in a successional grassland, Ecoscience 10 (2003) 525-531.

[88] Roy D.B., Rothery P., Moss D., Pollard E., Thomas J.A., Butterfly numbers and weather: predicting historical trends in abundance and the future effects of climate change, J. Anim. Ecol. 70 (2001) 201217

[89] Schelhaas M.J., Nabuurs G.J., Schuck A., Natural disturbances in the European forests in the 19th and 20th centuries, Glob. Change Biol. 9 (2003) 1620-1633.

[90] Schoeneweiss D.F., Water stress predisposition to disease - an overview, Cambridge University Press, University of Lancaster, 1986.

[91] Shi L.B., Guttenberger M., Kottke I., Hampp R., The effect of drought on mycorrhizas of beech (Fagus sylvatica $\mathrm{L}$.): changes in community structure, and the content of carbohydrates and nitrogen storage bodies of the fungi, Mycorrhiza 12 (2002) 303-311.

[92] Stefanescu C., Peñuelas J., Filella I., Effects of climatic change on the phenology of butterflies in the northwest Mediterranean Basin, Glob. Change Biol. 9 (2003) 1494-1506.

[93] Stokland J.N., Tomter S.M., Söderberg U., Development of dead wood indicators for biodiversity monitoring: experiences from Scandinavia, in: Marchetti M. (Ed.), Monitoring and indicators of forest biodiversity in Europe - From Ideas to operationality, EFI proceedings No. 51, Florence, 2004, pp. 207-226.

[94] Suffling R., Can disturbance determine vegetation distribution during climate warming? A boreal test, J. Biogeogr. 22 (1995) 501508

[95] Stampfli A., Zeiter M., Plant regeneration directs changes in grassland composition after extreme drought: a 13-year study in southern Switzerland, J. Ecol. 92 (2004) 568-576.

[96] Svenning J.-C., Deterministic Plio-Pleistocene extinctions in the European cool-temperate tree flora, Ecol. Lett. 6 (2003) 646-653.

[97] Swaty R.L., Deckert R.J., Whitham T.G., Gehring C.A., Ectomycorrhizal abundance and community composition shifts with drought: predictions from tree rings, Ecology 85 (2004) 10721084.
[98] Thomas F.M., Blank R., Hartmann G., Abiotic and biotic factors and their interactions as causes of oak decline in Central Europe, For. Pathol. 32 (2002) 277-307.

[99] Thomas J.A., Moss D., Pollard E., Increased fluctuations of butterflies populations towards the northern edges of species' ranges, Ecography 17 (1994) 215-220.

[100] Thomas S.C., Halpern C.B., Falk D.A., Liguori D.A., Austin K.A., Plant diversity in managed forests: understory responses to thinning and fertilization, Ecol. Appl. 9 (1999) 864-879.

[101] Thompson I.D., Flannigan M.D., Wotton B.M., Suffling R., The effects of climate change on landscape diversity: an example in Ontario forests, Environ. Monit. Assess. 49 (1998) 213-233.

[102] Thuiller W., Vayreda J., Pino J., Sabate S., Lavorel S., Gracia C., Large-scale environmental correlates of forest tree distributions in Catalonia (NE Spain), Glob. Ecol. Biogeogr. 12 (2003) 313-325.

[103] Tilman D., El Haddi A., Drought and biodiversity in grasslands, Oecologia 89 (1992) 257-264.

[104] Turner M.G., Dale V.H., Comparing large, infrequent disturbances: what have we learned? Ecosystems 1 (1998) 493-496.

[105] Vallauri D., André J., Blondel J., Le bois mort, une lacune des forêts gérées, Rev. For. Fr. 55 (2003) 3-16.

[106] Van Tol G., van Dobben H.F., Schmidt P., Klap J.M., Biodiversity of Dutch forest ecosystems as affected by receding groundwater levels and atmospheric deposition, Biodivers. Conserv. 7 (1998) 221228.

[107] Vygodskaya N.N., Schulze E.D., Tchebakova N.M., Karpachevskii L.O., Kozlov D., Sidorov K.N., Panfyorov M.I., Abrazko M.A., Shaposhnikov E.S., Solnzeva O.N., Minaeva T.Y., Jeltuchin A.S., Wirth C., Pugachevskii A.V., Climatic control of stand thinning in unmanaged spruce forests of the southern taiga in European Russia, Tellus B 54 (2002) 443-461.

[108] Walther G.R., Post E., Convey P., Menzel A., Parmesan C., Beebee T.J.C., Fromentin J.M., Hoegh-Guldberg O., Bairlein F., Ecological responses to recent climate change, Nature 416 (2002) 389-395.

[109] Wardle D.A., Bonner K.I., Barker G.M., Stability of ecosystem properties in response to above-ground functional group richness and composition, Oikos 89 (2000) 11-23.

[110] Wohlgemuth T., Bürgi M., Scheidegger C., Schütz M., Dominance reduction of species through disturbance - a proposed management principle for central European forests, Forest Ecol. Manage. 166 (2002) $1-15$.

[111] Yarnes C., Boecklen W., Abiotic factors promote plant heterogeneity and influence herbivore performance and mortality in Gambel's oak (Quercus gambelii), Entomol. Exp. Appl. 114 (2005) 87-95.

[112] Yordanov I., Velikova V., Tsonev T., Plant Responses to drought, acclimation, and stress tolerance, Photosynthetica 38 (2000) 171186

[113] Zhu-Dong L., Pei-Yu G., Kun-Jun W., Dian-Mo L., Effects of parental exposure to high temperature on offspring performance in the cotton bollworm, Helicoverpa armigera (Hübner) (Lepidoptera: Noctuidae): adaptive significance of the summer diapause, Appl. Entomol. Zool. 39 (2004) 373-379. 